\title{
Why Do We Tell the Same Stories?: Law Reform, Critical Librarianship, and the Triple Helix Dilemma
}

\author{
Jean Stefancic \\ University of Alabama - School of Law, jstefancic@law.ua.edu \\ Richard Delgado \\ University of Alabama - School of Law, rdelgado@law.ua.edu
}

Follow this and additional works at: https://scholarship.law.ua.edu/fac_working_papers

\section{Recommended Citation}

Jean Stefancic \& Richard Delgado, Why Do We Tell the Same Stories?: Law Reform, Critical Librarianship, and the Triple Helix Dilemma, (2012).

Available at: https://scholarship.law.ua.edu/fac_working_papers/53

This Working Paper is brought to you for free and open access by the Faculty Scholarship at Alabama Law Scholarly Commons. It has been accepted for inclusion in Working Papers by an authorized administrator of Alabama Law Scholarly Commons. 
FOR EDUCATIONAL USE ONLY

42 Stan. L. Rev. 207

Stanford Law Review

November, 1989

Essay

*207 WHY DO WE TELL THE SAME STORIES?: LAW REFORM, CRITICAL LIBRARIANSHIP, AND

THE TRIPLE HELIX DILEMMA

Richard Delgado [FNa]

Jean Stefancic [FNaa]

Copyright 1989 by the Board of Trustees of the Leland Stanford Junior University; Richard

Delgado and Jean Stefancic

This book first arose out of a passage in Borges, out of the laughter that shattered, as I read the passage, all the familiar landmarks of my thought-our thought, the thought that bears the stamp of our age and our geography - breaking up all the ordered surfaces and all the planes with which we are accustomed to tame the wild profusion of existing things, and continuing long afterwards to disturb and threaten with collapse our age-old distinction between the Same and the Other. This passage quotes a 'certain Chinese encyclopaedia' in which it is written that 'animals are divided into: (a) belonging to the Emperor, (b) embalmed, (c) tame, (d) sucking pigs, (e) sirens, (f) fabulous, ( $g$ ) stray dogs, (h) included in the present classification, (i) frenzied, $(j)$ innumerable, $(k)$ drawn with a very fine camelhair brush, $(\mathrm{l})$ et cetera, $(\mathrm{m})$ having just broken the water pitcher, $(n)$ that from a long way off look like flies.' In the wonderment of this taxonomy, the thing we apprehend in one great leap, the thing that, by means of the fable, is demonstrated as the exotic charm of another system of thought, is the limitation of our own, the stark impossibility of thinking that. [FN1]

\section{INTRODUCTION}

A remarkable sameness afflicts many scholarly articles, books, and doctoral dissertations. Most blame peer review, tenure and promotion requirements, and ivory-tower isolation. In law, additional restraints $* \mathbf{2 0 8}$ operate: stare decisis-the insistence that every statement be supported by a previous one, bar requirements, [FN2] and the tyranny of the casebook. [FN3]

Although a few legal innovators have managed to escape these constraints, an impartial observer casting an eye over the landscape of the law would conclude that most of our stories are very similar-variations on a theme of incremental reform carried out within the bounds of dominant Western tradition.

This essay focuses on an additional, seldom noticed means by which this sameness is created and maintained-namely, professionally prepared research and indexing systems. We single out three of these in wide use today: the Library of Congress subject heading system, the Index to Legal Periodicals, and the West Digest System. [FN4] These devices function like DNA; they enable the current system to replicate itself endlessly, easily, and painlessly. [FN5] Their categories mirror precedent and existing law; they both facilitate traditional legal thought and constrain novel approaches to the law.

A scholar who works within one or more of these systems finds the task of legal research greatly simplified. Beginning with one idea, such systems quickly bring to light closely related ideas, cases, and statutes. [FN6] The indexes are like a workshop full of well-oiled tools, making work easier. Relying on them exclusively, however, renders innovation more difficult; innovative jurisprudence may require entirely new tools, tools often left undeveloped or unnoticed because our attention is absorbed with manipulating old ones. [FN7] 
*209 A few legal innovators have risen to this challenge, [FN8] aided, from time to time, by mavericks and reformers in the library science field. [FN9] Computerized word-search strategies promise some hope of breaking the constraints imposed by older systems, but even they promise only a partial solution. [FN10] Nothing approaching a general solution is on the horizon.

This article demonstrates that existing indexing systems both inhibit and advance legal thought. Part II describes the principal systems and shows how they have developed. Part III illustrates the shackling effect of existing systems, using civil rights law as an example. Part IV indicates that this effect can sometimes be circumvented by using the current coordinate systems against themselves.

The categories contained in current indexing systems are like eyeglasses we have worn a long time. They enable us to see better, but lull us into thinking our vision is perfect and that there may not be a still better pair. Even when we discover a better pair, it, like the old, again sets limits on what we see. This process is inherent in our condition. We move from one set of limitations to another, finding only slightly greater freedom in our new condition. The beginning of wisdom is to understand and, insofar as we may, work around our limitations.

\section{CLASSIFICATION SYSTEMS IN LEGAL SCHOLARSHIP}

The three principal classification systems in use in the legal world $\mathbf{* 1 0}$ are the Library of Congress subject heading system, which describes library collections; various periodical indexes, including the Index to Legal Periodicals; and the West Digest System, which classifies legal decisions under various subject headings and "key numbers." A brief discussion and history of each system follows.

\section{A. Library of Congress Subject Headings}

The Library of Congress Subject Headings, now in its 11th edition, originated in 1898 when the Library of Congress adopted the List of Subject Headings for Use in Dictionary Catalogs as a basis for its own scheme. [FN11] The first edition of the Library of Congress Subject Headings was published in parts between 1909 and 1914. Later editions, appearing at irregular intervals, add new headings, reflect changes in conceptualization, and assure consistency. [FN12] The current edition contains 162,750 headings; its three volumes contain 4,164 pages. [FN13]

The list of headings, which is continually revised, expands at the rate of approximately 8,000 headings each year. [FN14] An editorial committee of the Library of Congress Subject Cataloging Division reviews proposals for new headings [FN15] to determine whether the revision is warranted and congruent with the existing Library of Congress Subject Headings structure. [FN16] Although most proposals originate in-house, catalogers at libraries that have a cooperative agreement with the Library of Congress may also propose changes. [FN17] Readers may be intrigued to know that the primary authorities for validating new law subject headings are Black's Law Dictionary and Current Law Index. [FN18]

Critics of the Library of Congress charge that its subject heading policy is conservative, [FN19] excessively cost-conscious, [FN20] and without a coherent*211 philosophy or structure. [FN21] Critics also charge that the Library of Congress's position of leadership magnifies these weaknesses because other libraries generally follow the Library of Congress's example. [FN22] Other critics complain that the system of headings simply replicates majoritarian politics and thought and gives too little attention to new, marginal, or renegade ideas. [FN23]

Still, many staunchly defend the Library of Congress system. [FN24] These defenders point out that the Library of Congress Subject Headings was never intended to be an all-inclusive set of categories. Rather, it was intended to enable the Library of Congress to deal with one single collection, its own. [FN25] Moreover, when the Library of Congress adopted the categories, they were adequate for the Library's then small collection. Most libraries, even those with specialized collections, chose to adopt the Library of Congress headings, and the Library maintained the essentials of the system even as the collection grew. As a result, the $* \mathbf{2 1 2}$ Library of Congress system extended far beyond the task for which it was originally designed. [FN26] Finally, defenders add that it is reasonable for the Library to take into account the cost of changes, 
especially when these changes will be multiplied at other libraries throughout the United States, and that the Library does add new categories when the need for them is shown. [FN27]

Impatience with the Library of Congress Subject Headings has led at least one other library system, that of Minnesota's Hennepin County, to produce its own subject heading list and make it available to other libraries. Hennepin's subject headings have been called both more current than Library of Congress Subject Headings and more sensitive to social and cultural changes. [FN28]

\section{B. Legal Periodical Indexes}

A number of services currently index legal periodicals. We focus on two in wide use that attempt to provide comprehensive coverage: the Index to Legal Periodicals and its competitor, Current Law Index. [FN29]

Until 1980 the Index to Legal Periodicals (the Index) was the only comprehensive guide to legal periodicals. [FN30] When the American Association of Law Libraries (the Association) produced the first volume in 1908; it covered only 40 journals. The Association soon broadened the coverage of the Index, however, and produced retrospective volumes back to 1898, linking the Index with the earlier Jones-Chipman Index which had provided coverage beginning in 1888. [FN31] H.W. Wilson Co. became the official publisher of the Index by 1918, and its owner in 1961. An Index to Legal Periodicals Committee of the American Association of Law Libraries functioned as an advisory body, suggesting new subject headings and consulting with the company on matters of policy. [FN32] Conflicts over subject headings, breadth of coverage, and other matters caused the Association to dissociate itself from the Index in 1978. [FN33]

*213 The Association's Index Committee then negotiated with Information Access Company to produce a new tool, Current Law Index, [FN34] which would compete with the Index to Legal Periodicals. [FN35] Current Law Index first appeared in 1980, indexing 660 periodicals and newspapers-about double the coverage of the Index to Legal Periodicals at the time. [FN36] The Information Access Company originally distributed Current Law Index in hard copy; it later added a cumulative version on microfilm, laserdisc, and online with slightly broadened coverage as Legal Resources Index or LEGALTRAC. [FN37] Coverage for Current Law Index in any of its forms extends back only to 1980; for articles published before that time the researcher must consult the Index to Legal Periodicals. The Index to Legal Periodicals is available in hard copy, online through various services, on optical disc, but not on microform. [FN38]

Both indexing services, the Index to Legal Periodicals and Current Law Index, provide subject access, but they derive their headings from different sources. The Index to Legal Periodicals lists Black's Law Dictionary (published by West) and West's Legal Thesaurus/Dictionary as sources of authority for its subject headings. [FN39] Current Law Index is based on Library of Congress subject headings with modifications. [FN40] The Library of Congress lists Black's Law Dictionary and Current Law Index as principal sources used to establish authority. [FN41] The circle is nearly complete. [FN42]

\section{*214 C. The West Digest System}

The West Digest System began as an aid to legal researchers. Prior to its inception there was no comprehensive or uniform indexing of state and federal cases. [FN43] As a result, late 19th and early 20th century American scholars encountered a great deal of difficulty as they struggled with the unwieldy body of American law. [FN44] Henry Terry aptly summarized the early quandary: "In substance our law is excellent, full of justice and good sense, but in form it is chaotic. It has no systematic arrangement which is generally recognized and used, a fact which greatly increases the labors of lawyers and causes unnecessary litigation." [FN45] Some scholars note that the inability of lawyers to follow the development of the law either nationally or locally threatened stare decisis because of the "enormous and unrestrained quantity" of competing reporters, which "discouraged research and inevitably led to a conflict among authorities." [FN46]

In 1876 the West Company published its first compilations of court reports, The Syllabi. [FN47] By 1879 the company published a permanent edition, the North Western Reporter, 
which included judicial decisions of the Dakota Territory, Iowa, Michigan, Minnesota, Nebraska, and Wisconsin. [FN48] Facing little competition, West blanketed the country with its seven regional reporters that came to be known as the National Reporter* $\mathbf{2 1 5}$ System. The system today covers states, the various federal courts, and some sets of statutes.

The West Company built its success on its national coverage, which offered both access to myriad judicial decisions and an efficient means of managing them. [FN49] To assist lawyers searching for precedent, West provided a uniform plan of headnotes and indexing in all of its reporters. [FN501 It issued the first American Digest Annual in 1887. [FN51] In its first century, West published about two and a half million opinions with an average of five headnotes each; it currently publishes about sixty thousand cases a year. [FN52]

West's great advantage was a uniform plan of headnotes and indexing in all its reporters. The plan's originator, John A. Mallory, joined West's editorial department when West acquired a smaller competitor. Mallory developed the American Digest Classification Scheme and the original Key Number Digest. [FN53]

In 1898 the American Bar Association endorsed the Digest, reinforcing West's central role in indexing and reporting United States case law. [FN54] Other authorities have been more guarded. [FN55] To them, what began as a system abstracted and constructed out of its primary source data-judicial opinions- had transformed itself into a rigid grand scheme into which the law itself had to be fit.

West has weathered this and other criticisms [FN56] in part by its cautious and somewhat secretive nature. The company has released little about its internal procedures. A 1983 article states that eight classification editors assign keynotes to cases; thirty-four general editors who work under them write headnotes and synopses. Change comes slowly; The topic "Labor" received a heading in the 1950s, and until recently West classified "Workers' Compensation" under "Master and Servant" *216 law. [FN57]

West faced a major challenge in 1970 when Mead Data Central introduced LEXIS, the first full-text database containing judicial opinions. The familiar world of print now had to compete with a randomly available universe accessible through any combinations of search words the user framed. WESTLAW, West's response to LEXIS, appeared in the mid-1970s and has undergone continual modification and improvement. [FN58] Law libraries, firms, and government agencies now widely use both databases. [FN59]

A half century after the early "legal science" classification debates, [FN60] legal research and information specialists had a similar discussion. A critical issue in this debate was the extent to which word-based, computer-assisted searching could, or should, replace the old-fashioned, thesaurus-based searching. Some specialists felt as if the indexer had vanished, leaving the searcher to cope with text and intended meanings unaided. [FN61]

\section{CLASSIFICATION SYSTEMS AND THE REPLICATION OF PREEXISTING THOUGHT: THE TRIPLE HELIX DILEMMA}

Existing classification systems serve their intended purpose admirably: They enable researchers to find helpful cases, articles, and books. Their power is instrumental; once the researcher knows what he or she is looking for, the classification systems enable him or her to find it. Yet, at the same time, the very search for authority, precedent, and hierarchy in cases and statutes can create the false impression that law is exact and deterministic-a sciencewith only one correct answer to a legal question. [FN62]

Moreover, in many instances the researcher will not know what he or she is looking for. The situation may call for innovation. The indexing $* \mathbf{2 1 7}$ systems may not have developed a category for the issue being researched, or having invented one, have failed to enter a key item into the database selected by the researcher, thus rendering the system useless. The systems function rather like molecular biology's double helix: They replicate preexisting ideas, thoughts, and approaches. [FN63] Within the bounds of the three systems, moderate, incremental reform remains quite possible but the systems make foundational, transformative innovation difficult. [FN64] Because the three classification systems operate in a coordinated network of information retrieval, we call the situation confronting the lawyer or scholar trying to break free from their constraints the triple helix dilemma. 
To illustrate this dilemma, consider the range of listings found under the general heading of civil rights. Recently, scholars have begun $* \mathbf{2 1 8}$ to question basic premises in this area of law. [FN65] Some have challenged the utility of White-generated theory developed in whitedominated academic milieux. [FN66] Others have called into question key presuppositions of civil rights cases and statutes, observing that present legal remedies generally benefit Whites more than Blacks [FN67] and provide relief for Blacks only when they do not impose unacceptable costs on elite Whites. [FN68] They also cast doubt on such cherished beliefs as that Blacks are experiencing steady socio-economic gains, [FN69] that affirmative action enables many to move ahead in the workplace, [FN70] and that the foremost challenge facing the civil rights community is attacking individual and institutional racism through education, litigation, and progressive legislation. [FN71]

These writers have found current legal categorization schemes a hindrance more than a help. A glance at the standard categories shows why; each system bears a strong imprint of the incremental civil rights approach these writers decry. [FN72] The Index to Legal Periodicals and Decennial Digest, for example, lead the reader to works on civil rights, [FN73] employment discrimination, [FN74] and school integration or desegregation, [FN75] but contain no entry for hegemony or interest convergence. [FN76] The Index*219 to Legal Periodicals lacked an entry for critical legal studies until September 1987, nearly a decade after the movement began. [FN77] The Decennial Digest contains entries on slums [FN78] and miscegenation. [FN79] To find cases on ghettos, one must look in the Descriptive Word Index under slums, which refers the searcher to public improvements under the topic municipal corporations. Another index contains an entry labeled, simply, races. [FN80] None of the major indexes contains entries for legitimation, false consciousness, or many other themes of the "new" or critical race-remedies scholarship. Indeed, a researcher who confined himself or herself to the sources listed under standard civil rights headings would be unlikely to come in contact with these ideas, much less invent them on his or her own. As a thought experiment, we invite readers to predict the category or categories under which indexers will place this article. [FN81]

As an example of the channeling effect of current legal categorization schemes, consider the situation of Black women wishing to sue for job discrimination directed against them as Black women. Attorneys searching for precedent will find a large body of case and statutory law under the headings "race discrimination" and "sex discrimination." [FN82] No category combines the two types of discrimination (although computer-assisted researchers can better approximate a cross-referencing system by combining the two categories in the same search). Because of the structure of the indexing systems, attorneys for Black women $* \mathbf{2 2 0}$ have filed suit under one category or the other, or sometimes both. [FN83] Recently, critics have pointed out that under this approach, Black women will lose if the employer can show that it has a satisfactory record for hiring and promoting women generally (including White women) and similarly for hiring Blacks (including Black men). The employer will prevail even if it has been blatantly discriminatory against Black women because the legal classification schemes treat Black women like the most advantaged members of each group (White women and Black men, respectively), when they are probably the least advantaged. [FN84]

To correct this problem, legal scholars have recently created the concept of intersectionality and have urged that Black women's unique situation be recognized, named, and addressed. [FN85] Of course, more than the absence of an index category created the Black women's dilemma. [FN86] But until the lacuna was recognized and named, legal classification systems made it difficult to notice or redress. Reform now will require disaggregation of the current dichotomous classification scheme, creation of a more complex one, and reorganization of the relevant cases and statutes accordingly.

Word-based computer searches solve only part of the problem. [FN87] Some key articles and cases dealing with concepts such as civil disobedience or legitimation do not refer to them by name; others that do are not included in standard legal databases. [FN88] The efficiency of word-based searches depends on the probability that the searcher and the $* \mathbf{2 2 1}$ court have used the same word or phrase for the concept in question. [FN89] Computers may be excellent means of finding cases about cows that wander onto highways. They are less useful in finding cases that illustrate or discuss more complex or abstract concepts. [FN90] Word-based computer searches provide even less assistance to the researcher in coining a concept or word. 
They are most useful once someone has proposed the concept or word and an editor has entered the text containing it into the database. [FN91] Finally, computerized research can "freeze" the law by limiting the search to cases containing particular words or expressions. Research should encourage browsing and analogical reasoning. [FN92] Paradoxically, computerassisted research can discourage innovation and law reform. [FN93]

LEXIS, WESTLAW, and their users are now more sophisticated than in the early days when simple questions stumped the companies' demonstrators, but many of these problems remain. [FN94] Ironically, a $* \mathbf{2 2 2}$ number of observers suggest adding subject indexing to the LEXIS and WESTLAW systems, thus interposing another human being's subjective judgment between researcher and text-the very thing that computer-assisted legal research was designed to replace. [FN95]

Existing legal research systems thus tug the researcher toward the familiar, the conventional. The legal researcher quickly discovers pre-existing ideas, arguments, and legal strategies and is rewarded for staying on familiar ground. Striking out on one's own is costly and inefficient. Courts, other scholars, and one's adversary will all frame the problem in common terms; the temptation is almost irresistible. Stepping outside the framework is like abandoning a well-known and well-mapped coast for the uncharted sea. We never realize that we cannot embark on certain types of journeys armed only with conventional maps.

Preexisting legal thought thus replicates itself. The indexes put one set of ideas at the researcher's disposal; it becomes difficult to visualize another, or imagine that one could exist. [FN96] Nevertheless, a few thinkers do manage to escape the trammels we have discussed and propose new ways of thinking about legal reality. The next section explores ways to achieve this innovation, including how to turn the existing classification systems to the advantage of the legal transformer.

\section{HOW TO BREAK THE CIRCLE}

We can sometimes break the cycle of repetitive thought and scholarship and achieve genuine innovation. Just as in evolution, where organisms regularly appear with traits not present in their ancestors, each generation presents us with a few legal thinkers able to break free from the constraints of preexisting thought and offer striking and effective new approaches. [FN97]

*223 Often, but not always, these thinkers will be individuals whose life experiences have differed markedly from those of their contemporaries. [FN98] They may be members of marginal groups, [FN99] or persons who are in other ways separated from the mainstream. [FN100] In civil rights scholarship, one thinks of Derrick Bell, the innovative Black scholar whose work on interest-convergence, the usefulness of standard remedies, and parables of racial injustice is challenging the civil rights community to reexamine long-held assumptions. [FN101] We should heed these divergent individuals. Their ideas offer the possibility of legal transformation and growth. Like nature's mutant or hybrid, they offer the infusion of new material needed to retain the vitality of our system of thought.

Can others acquire the skill which some possess at transcending conventional legal categories and modes of thought? In a recent article, Richard Sherwin implies that "suspicion" may be an acquired ability which we can sharpen through experience. [FN102] We are less sanguine. One scholar suggests that creativity is neither widely nor predictably distributed among the human population, and that it is not easily acquired. [FN103] In law and politics innovative potential may be linked with "double consciousness" [FN104] or life experiences that in some way deviate from the norm. [FN105] The incentive to innovate may be stronger in persons for whom the current system does not work well. The pressures of a lawyer's or librarian's life may be hinder creativity. [FN106] Law professors are not free of all those pressures-they have classes to teach, papers to grade, meetings to attend, and other minutiae of academic life. Perhaps we can only try to look beyond the conventional and applaud those who, often for unknown reasons, actually do so.

Our bondage offers a second route to transformation. Categories in $\mathbf{* 2 4}$ the principal legal indexing systems are explicit. They exist externally, in printed and electronic media, as well as within our minds. [FN107] If we examine them, we will see an outline of the structure of 
traditional legal thought. [FN108] That structure will reveal what previous courts and writers have recognized and what indexers have faithfully recorded. By inspecting this record, we may gain a glimpse of the very conceptual framework we have been wielding in scrutinizing and interpreting our societal order. [FN109] We may then inquire whether that framework is the only, or the best means of doing so. We may turn that system on its side and ask what is missing.

Our earlier review of the way civil rights categories limit thought and innovation showed that open-minded inquiry is not easy. Yet, a skeptical examination of what exists may sometimes prompt a researcher to ask why something else does not exist. For example, a feminist study group recently explored a legal issue affecting women. [FN110] Although the members knew of several cases that dealt with the problem, West indexers had created no category for it. Thus, the only way to find the cases was to know about and shepardize one or perform a word-based computer search employing as many descriptive terms and synonyms as possible. The feminists, sophisticated in ways of patriarchy and mindset, concluded from their experience that the oversight was not merely inadvertent, but rooted in the structure of male-dominated law. [FN111] Less sophisticated users might have blamed themselves $* \mathbf{2 2 5}$ for not finding the right section of the Digest or concluded that the absence of a category was an isolated oversight, attributable perhaps to bibliographic lag, that would be cleared up in the next edition. [FN112]

Going beyond standard legal categories and conventional wisdom is difficult even when we are only looking for moderate, incremental reform that does little to tax one's imagination or the traditional legal system. [FN113] Where one desires more fundamental change, the task is made more difficult by stare decisis, bar requirements, and the standardizing effect of law school casebooks. These forces set up a powerful, largely unconscious, preference for the familiar, rendering legal innovation difficult.

This article had focused on an additional barrier to legal transformation: the principal indexing and research systems. These systems confine thought to the familiar categories of traditional legal theory. They quickly and painlessly enable the researcher to locate books, articles, and cases within that tradition, but they are unlikely to bring to light transformative ideas and analogies. The principal indexing systems' ease and economy encourage an unconscious self-censorship of the mind that is difficult to elude, indeed even to recognize. [FN114]

We discussed two means by which we can sometimes escape the constraints of current legal categories, to examine the framework that underlies legal reality. These strategies enable us to discover the intricacies and limitations inherent in our framework, make allowances for them, and so view reality in a truer, fairer light. Yet, an expanded framework will in time become a further prison, requiring yet another struggle to break free. We can only hope to progress from one degree of nonfreedom to another, slightly less confining one. Vigilance and effort are required to achieve even these modest gains.

[FNa] Professor of Law, University of Wisconsin. J.D., University of California, Berkeley (Boalt Hall), 1974.

[FNaa] Technical Services Librarian, University of San Francisco Law Library. M.L.S., Simmons College, 1963, M.A., University of San Francisco, 1989.

We gratefully acknowledge the research assistance of Charles Church in the preparation of this article. Our work was supported by a grant from the Ameritech Foundation.

\section{[FN1]. MICHEL FOUCAULT, THE ORDER OF THINGS: AN ARCHAEOLOGY OF THE HUMAN} SCIENCES XV (1973).

[FN2]. Bar requirements, which are relatively similar from state to state, channel lawyers' preparation into similar paths, conveying the message that other legal questions are peripheral or subordinate. 
[FN3]. Casebooks convey implicit normative messages by the way in which their authors arrange the cases, comments, and notes. See, e.g., LAWRENCE M. FRIEDMAN \& STEWART MACAULAY, LAW AND THE BEHAVIORAL SCIENCES vii-ix (1977); Mary Joe Frug, Re-reading Contracts: A Feminist Analysis of a Contracts Casebook, 34 AM. U.L. REV. 1065 (1985); Duncan Kennedy, Legal Education as Training for Hierarchy, in THE POLITICS OF LAW: A PROGRESSIVE CRITIQUE 40, 43-44 (D. Kairys ed. 1982).

[FN4]. Along with the Index to Legal Periodicals, we include its competitor, Current Law Index. We exclude from consideration other less widely used research tools, such as American Jurisprudence, American Law Reports, and Corpus Juris Secundum.

[FN5]. See MARTIN MAYER, THE LAWYERS 431 (1966) (West Publishing Company shapes law by establishment of headnotes); ROBERT STEVENS, LAW SCHOOL: LEGAL EDUCATION IN AMERICA FROM THE 1850S TO THE 1980S 132-33 (1983) (West's headnote system encourages mechanical, atheoretical scholarship); Robert C. Berring, Full-Text Databases and Legal Research: Backing into the Future, 1 HIGH TECH. L.J. 27, 35-36 (1986) (lawyers learn to think according to West headnotes). But see Tom Woxland, My Favorite Headnotes, 6 LEGAL REFERENCE SERVICES Q., nos. 1/2, 1986, at 119 (not all headnote editors mindless drudges).

[FN6]. See KARL N. LLEWELLYN, JURISPRUDENCE: REALISM IN THEORY AND PRACTICE 82 (1962)("threat of the available"). Nonlegal classifiers face the same hazard. For examples drawn from ancient literature, see ARISTOTLE, DE GENERATIONE ANIMALIUM 783B-789 (A.L. Peck trans. 2d ed. 1943).

[FN7]. The very rules of structure that enable editors and indexers to place an article or case into particular categories are themselves matters of interpretation, custom, and ultimately politics, which in time have come to seem natural and inevitable. See Steven M. Barkan, Deconstructing Legal Research: A Law Librarian's Commentary on Critical Legal Studies, 79 LAW LIBR. J. 617, 632-34 (1987); see also BASIL B. BERNSTEIN, On the Classification and Framing of Educational Knowledge, in 1 CLASS, CODES, AND CONTROL: TOWARDS A SOCIOLOGY OF LANGUAGE 202, 202 (1971)(the way society selects and classifies public knowledge "reflects both the distribution of power and the principles of social control"); Groups Challenge Library's Holocaust-Revisionist Titles, 19 AM. LIBR. 640 (1988) (decisions to categorize material in one form or another, e.g., "straight" or with commentary, are ultimately political); Duncan Kennedy, The Structure of Blackstone's Commentaries, 28 BUFFALO L. REV. 209, 215-16 (1979) (all legal categories are essentially lies, artificial constructs designed to make things seem more orderly than they are, and yet, paradoxically, we cannot live without them).

[FN8]. See Barkan, supra note 7; Robert C. Berring, Legal Research and Legal Concepts: Where Form Molds Substance, 75 CALIF. L. REV. 15 (1987); Virginia Wise, Of Lizards, Intersubjective Zap, and Trashing: Critical Legal Studies and the Librarian, 8 LEGAL REFERENCE SERVICES Q., nos. $1 / 2,1988$, at 7 .

[FN9]. See, e.g., Jim Dwyer, Alternative Perspectives: A Conversation with Sandy Berman, TECHNICALITIES, Oct. 1986, at 3. Minnesota's Hennepin County Library and its spokesperson, Sanford Berman, have served as leaders in urging the Library of Congress to eliminate while Western bias and insulting or reactionary headings. See, e.g., SANFORD BERMAN, PREJUDICES AND ANTIPATHIES: A TRACT ON THE LC SUBJECT HEADS CONCERNING PEOPLE (1971); HENNEPIN COUNTY LIBRARY CATALOGING BULLETIN (1987); HENNEPIN COUNTY LIBRARY EXPORT AUTHORITY LIST (1977); HENNEPIN COUNTY LIBRARYYYYYY ONLINE CATALOG NEWS; see also COMMITTEE FOR THE DEVELOPMENT OF SUBJECT ACCESS TO CHICANO LITERATURE, CHICANO THESAURUS FOR INDEXING CHICANO MATERIALS (1979); RUTH DICKSTEIN, VICTORIA A. MILLS \& ELLEN J. WAITE, WOMEN IN LC'S TERMS: A THESAURUS OF LIBRARY OF CONGRESS SUBJECT HEADINGS RELATING TO WOMEN (1988); Richard Chabrán, Latino Reference Arrives, 18 AM. LIBR. 384 (1987). 
[FN10]. See Berring, supra note 5, at 34, 41-42; Berring, supra note 8, at 25-27; see also text accompanying notes 87-93 infra (arguing that computers are likely to bring only limited freedom).

[FN11]. LIBRARY OF CONGRESS SUBJECT HEADING viii (11th ed. 1988).

[FN12]. See id.

[FN13]. Id. at vii.

[FN14]. Id.

[FN15]. Id.; see also LIBRARY OF CONGRESS SUBJECT CATALOGING DIVISION, SUBJECT CATALOGING MANUAL: SUBJECT HEADINGS at H 187 (1985) (giving criteria for establishing a new heading). The headings are revised by the Library of Congress Subject Cataloging Division whose current chief is Mary Pietris. Mary K.D. Pietris, L.C: New Manual, Not Code, Needed, 18 AM. LIBR. 958 (1987).

[FN16]. LIBRARY OF CONGRESS SUBJECT CATALOGING DIVISION, supra note 15 , at H 202:1, 3.

[FN17]. LIBRARY OF CONGRESS SUBJECT HEADINGS, supra note 11, at vii.

[FN18]. PETER ENYINGI, MELODY BUSSE LEMBKE \& RHONDA LAWRENCE MITTÁN CATALOGING LEGAL LITERATURE: A MANUAL ON AACR2 AND LIBRARY OF CONGRESS SUBJECT HEADINGS FOR LEGAL MATERIALS 370 (2d ed. 1988).

[FN19]. Sanford Berman, Not Funny Any More, LIBR. J., June 1, 1988, at 80 (airplane accidents listed under "Aeronautics-Accidents," horseshoe crabs hiding under "Limulus Polyphemus," and materials on the Palestinian Liberation Organization listed under "Munazzamat Al-Tahrir AlFilastiniyah"); Ronald Crovisier \& Sheila S. Intner, Classification for Astronomy: The QB Schedule of the Library of Congress Classification, 7 CATALOGING \& CLASSIFICATION Q., no. 3, 1987, at 23 (Library of Congress's science schedules still show signs of their Victorian origins); Robert P. Holley Constraints of the $3 \times 5$ Card, 4 CATALOGING \& CLASSIFICATION Q., no. 1, 1983, at 29, 34-35 (Library of Congress conservative about changing headings); William E. Studwell, The 1990s: Decade of Subject Acces, 18 AM. LIBR. 958, 960 (1987) (Library of Congress's Subject Cataloging Division, the only organization substantially engaged in developing Library of Congress subject headings, works slowly).

The revision of Library of Congress Subject Headings may also be limited by the principle of findability. For example, changing the subject heading "Eskimos" to "Inuits" would better reflect the self-referential practice of this ethnic group, but for many library users it would also complicate the search. See Dwyer, supra note 9, at 7.

[FN20]. See David Henige, Library of Congress Subject Headings: Is Euthanasia the Answer?, 8 CATALOGING \& CLASSIFICATION Q., no. 1, 1987, at 7, 13-14; Robert P. Holley \& Robert E. Killheffer, Is There an Answer to the Subject Access Crisis?, 1 CATALOGING \& CLASSIFICATION Q., nos. 2/3, 1982, at 125, 128, 130; ; Monika Kirtland \& Pauline Cochrane, Critical Views of LCSH-A Bibliographic and Bibliometric Essay, 1 CATALOGING \& CLASSIFICATION Q., nos. 2/3 1982, at 71, 76; See also LIBRARY OF CONGRESS SUBJECT HEADINGS, supra note 11, at ix (conceding feasibility weighed in deciding whether to make changes). Simply changing a subject heading to accord with current usage, for example, changing "Near East" to "Middle East," may entail thousands of individual record changes. Eliezer Chammou, Near or Middle East? Choice of Name, 7 CATALOGING \& CLASSIFICATION Q., no. 3, 1987, at 105, 117.

[FN21]. Holley, supra note 19, at 32; Kirtland \& Cochrane, supra note 20. Descriptive cataloging has been codified by several major library bodies. See ANGLO-AMERICAN CATALOGUING RULES 
(2d ed. 1978) (known as AACR2). Still, no similar code exists for subject headings. E.g., William E. Studwell, Why Not an "AACR" for Subject Headings?, 6 CATALOGING \& CLASSIFICATION Q., no. 1,1985 , at 3,4 .

[FN22]. Library of Congress cataloging practices have become the standard for most libraries in the United States. See Patricia L. Piper \& Cecilia Hing Ling Kwan, Cataloging and Classification, in LAW LIBRARIANSHIP: A HANDBOOK 359-62 (H. Mueller \& P. Kehoe eds. 1983). The enormous labor costs of cataloging and the accessibility of the Library of Congress's classification contribute to the dependence of other libraries on the Library of Congress. JESSICA L. MILSTEAD, SUBJECT ACCESS SYSTEMS: ALTERNATIVES IN DESIGN 10 (1984); Jessica L. Milstead, Indexing for Subject Cataloguers, 3 CATALOGING \& CLASSIFICATION Q., no. 4, 1983, at 37, 39. One could argue that the virtual monopoly of the Library of Congress over cataloging amounts to a federal subsidy of library cataloging efforts-one that has so far prevented any real competition to the Library of Congress system.

[FN23]. S. BERMAN, supra note 9; Sanford Berman, Out of the Kitchen-But Not Into the Catalog, 2 TECH. SERVICES Q. 167 (1984) (focusing on biases against women revealed through the Library of Congress subject heading policies); Diane Choquette, The New Religious

Movements Research Collection: A History and Description of Alternative Subject Cataloging, 2 TECH. SERVICES Q. 19 (1984).

[FN24]. See, e.g., Library of Congress Response to "Library of Congress Subject Headings: Is Euthanasia the Answer?," 8 CATALOGING \& CLASSIFICATION Q., 1987, no. 1, 1987 at 21; Pietris, supra note 15.

[FN25]. See LIBRARY OF CONGRESS SUBJECT HEADINGS, supra note 11 , at viii.

[FN26]. See, e.g., Holley, supra note 19, at 31, 32; William Mischo, Library of Congress Subject Headings: A Review of the Problems, and Prospects for Improved Subject Access, 1

CATALOGING \& CLASSIFICATION Q., nos. 2/3, 1982, at 105. See generally FRANCES MIKSA, THE SUBJECT IN THE DICTIONARY CATALOG FROM CUTTER TO THE PRESENT (1983).

[FN27]. LIBRARY OF CONGRESS SUBJECT HEADINGS, supra note 11, at ix.

[FN28]. See Dwyer, supra note 9; Randall W. Scott, HCL Bibliographic Products (Book Review), LIBR. J., May 15, 1988, at 64.

[FN29]. For an appraisal of less widely used tools, including Annual Legal Bibliography (Harvard); Index to Periodical Articles Related to Law (J.M. Jacobstein \& R. M. Mersky eds.); Social Science Citation Index (J.M. Jacobstein \& R.M. Mersky eds.); and Current Index to Legal Periodicals (University of Washington), see Thomas Steele, The Index to Legal Periodicals and Current Law Index-A Comparison, 1 LEGAL REFERENCE SERVICES Q., no. 4, 1981, at 43.

[FN30]. Richard Leiter, A History of Legal Periodical Indexing, 7 LEGAL REFERENCE SERVICES Q., no. 1, 1987, at 35, 45-46.

[FN31]. Id. at 37-40.

[FN32]. Id. at 41-42.

[FN33]. Id. at 45. Among the chief objections to the older version of the Index was that it "was based on an inadequate thesaurus, one that contained too few subject headings to represent the topics covered by its collection." Daniel P. Dabney, The Curse of Thamus: An Analysis of Full-Text Legal Document Retrieval, 78 LAW LIBR. J. 5, 12 n.9 (1986) (citing Association of American Law Schools Committee on Libraries, Report of the Subcommittee on the Index to Legal Periodicals, in PROCEEDINGS OF THE 1976 ANNUAL MEETING OF THE ASSOCIATION OF 
AMERICAN LAW SCHOOLS, pt. 1, § 1, 30, 33-34 (1975)).

[FN34]. Leiter, supra note 30, at 46.

[FN35]. Howard A. Hood, Review of Current Law Index, 16 INT'L J. LEGAL INFO. 123 (1988);

Steele, supra note 29 , at 43.

[FN36]. Leiter, supra note 30 , at 46.

[FN37]. Legal Resources Index is the second-generation index produced by Information Access Company, the publisher of Current Law Index. Available on microfilm, Legal Resources Index increases the coverage of the Current Law Index by indexing articles on legal subjects appearing in national newspapers. Legal Resources Index also merges the bound index of Current Law Index beginning in 1980, thus eliminating the tedious search through separate annual editions and monthly updates. The system is expensive and cumbersome and not widely used in its microform version. LEGALTRAC, the latest Information Access Company index format, is the equivalent of Legal Resources Index on compact disc with access through a computer screen and keyboard. LEGALTRAC can be searched by author, subject, or case. Legal Resources Index is also available online through the DIALOG database, which permits searchers to use Boolean logic in devising search strategies, and through two other computerized legal research tools. LEXIS and WESTLAW. KENT C. OLSON \& ROBERT C. BERRING, PRACTICAL APPROACHES TO LEGAL RESEARCH 92-93 (1988).

[FN38]. The online services include WILSONLINE, LEXIS, AND WESTLAW. Hood, supra note 35, at 127.

[FN39]. INDEX TO LEGAL PERIODICALS: THESAURUS iv (1988).

[FN40]. 8 CURRENT LAW INDEX iii (1987); K. OLSON \& R. BERRING, supra note 37, at 92 ("CLI uses Library of Congress subject headings instead of the more general Wilson headings.").

[FN41]. P. ENYINGI, M. LEMBKE \& R. MITTÁN, supra note 18, at 370; see also text accompanying note 18 supra.

[FN42]. Circularities are also rampant within particular systems. A 1988 search on LEGALTRAC of the term "sexual orientation" provided a 'see also' reference to "sexual deviation" which carried a 'see' reference from "sexual perversion." Under "sexual deviation" was a 'see also' reference to "sexual masochism." The University of San Francisco Law Library notified Information Access of these peculiarities, and the headings have since been revised. Printouts are on file with the authors. See generally Mary Dykstra, Can Subject Headings Be Saved?, LIBR. J., Sept. 15, 1988, at 55; Mary Dykstra, LC Subject Headings Disguised as a Thesaurus, LIBR. J., Mar. 1, 1988, at 42, 44-46.

[FN43]. There was, however, lively debate in a number of law reviews over how law should be classified. See WILLIAM MARVIN, WEST PUBLISHING COMPANY: ORIGIN, GROWTH, LEADERSHIP 67 (1969); Thomas Woxland, "Forever Associated with the Practice of Law": The Early Years of the West Publishing Company, 5 LEGAL REFERENCE SERVICES Q., no. 1, 1985, at 115, 116; see also Berring, supra note 8, at 21-25. The accuracy, affordability, comprehensive jurisdictional coverage, uniformity of reporting format, regularity of publication, and a subject heading system into which all cases could be fit made West's publications attractive to lawyers. This ability to pull together an increasingly disjointed body of case law preserved the myth of a natural structure underlying the common law and thus reinforced the way most practitioners thought about the law, despite the skepticism of legal realists. For a brief review of several other writers' claims that the West Company has helped to shape the substance of American law, see Barkan, supra note 7, at 633 n.79. 
[FN44]. See, e.g., Albert Kocourek, Classification of Law, 11 N.Y.U. L.Q. REV. 319 (1934); Roscoe Pound, Classification of Law, 37 HARV. L. REV. 933 (1924); Henry T. Terry, Arrangement of the Law, 15 U. ILL. L. REV. 61 (1920); Charles C. Ulrich, A Proposed Plan of Classification for the Law, 34 MICH. L. REV. 226 (1935).

[FN45]. Terry, supra note 44, at 61.

[FN46]. Woxland, supra note 43, at 123.

[FN47]. The company now known as West Publishing Company started as John B. West \& Co. and published its first reporter, The Syllabi, in St. Paul, Minnesota. WEST, LAW FINDER 5 (1988). West's success spelled secondary status for the English model of selective reporting, carried on chiefly by American Law Reports, and for attempts to simplify and codify American case law, such as the Restatement. The West model of "comprehensive reporting of all decisions, no matter how boring or stupid," is entrenched; each year about 65,000 decisions are added to the National Reporter System, along with about 65,000 more memorandum decisions. Berring, supra note 8 , at 21-23 \& n.38.

[FN48]. WEST, supra note 47, at 5.

[FN49]. Woxland, supra note 43, at 123.

[FN50]. W. MARVIN, supra note 43, at 39.

[FN51]. Id. at 68.

[FN52]. Woxland, supra note 5, at 120 (historical); Jill Abramson, John Kennedy \& Ellen Joan Pollock, Inside the West Empire: They Define American Jurisprudence-And Make Millions in the Process. Can They Keep it Up?, AM. LAW., Oct. 1983, at 90, 90 (current). But cf. Berring, supra note 8 , at 23 n.38 (reporting slightly larger current figure).

[FN53]. To include all noteworthy points of opinions, a digest would need nearly as many key numbers as cases; stacking of index terms-topics, subtopics, sub-subtopics, etc.-is unwieldy and calls for some guesswork. See Dabney, supra note 33, at 13; see also FREDERICK C. HICKS, MATERIALS AND METHODS OF LEGAL RESEARCH 233 (3d ed. 1942); W. MARVIN, supra note 43 , at 70 .

[FN54]. See W. MARVIN, supra note 43, at 74.

[FN55]. See Berring, supra note 5, at 33-36; Ulrich, supra note 44, at 226.

[FN56]. Inherent in the system are four problems. First, editorial errors are uncommon, but a misplaced headnote means a "lost" case. Second, over-complex indexing requires familiarity for efficient use. Third, a rigid topic structure that is resistant to change is perhaps responsible in part for the conservative development of United States law. Finally, West's editors, in their role as mediators between researcher and opinion, infuse their own judgment into the system which is patterned by the key number system and which is more attuned to finding conformity in judicial opinions than originality or subtlety. See Berring, supra note 5, at 33-37.

[FN57]. Abramson, Kennedy \& Pollock, supra note 52, at 92.

[FN58]. Id. at 94-95.

[FN59]. For an introduction to the capabilities and limitations of WESTLAW and its competitor LEXIS, see Berring, supra note 5, at 38-60. For a description of the early development of WESTLAW, see James A. Sprowl, The Westlaw System-A Different approach to Computer- 
Assisted Legal Research, 16 JURIMETRICS J. 142 (1976). For the early development of LEXIS, see James A. Sprowl, Computer-Assisted Legal Research-An Analysis of Full Text Document Retrieval Systems, Particularly the LEXIS System, 1976 AM. B. FOUND. RES. J. 175, 189.

[FN60]. See note 44 supra and accompanying text.

[FN61]. See Al Coco, Full-Text vs. Full-Text Plus Editorial Additions: Comparative Retrieval Effectiveness of the LEXIS and WESTLAW Systems, 4 LEGAL REFERENCE SERVICES Q., no. 2, 1984, at 27, 28; Pamela Jeffers Gregory, WESTLAW and LEXIS: Comparisons for the Public Terminal Applications, 2 LEGAL REFERENCE SERVICES Q., no. 3, 1982, at 101; A Robert Menanteaux, A User's Comparison of WESTLAW and LEXIS, 2 LEGAL REFERENCE SERVICES Q., no. 2, 1982, at 19; William W. Wells, Jr., LEXIS and WESTLAW: The Strengths and Weaknesses, 2 LEGAL REFERENCE SERVICES Q., no. 2, 1982, at 51.

[FN62]. See, e.g., William F. Birdsall, The Political Persuasion of Librarianship, LIBR. J., June 1, 1988, at 75 (classifications based on ideology are inevitably normative, but few indexers realize this); David Kairys, Legal Reasoning, in THE POLITICS OF LAW: A PROGRESSIVE CRITIQUE, supra note 3 , at 11 (legal reasoning basically normative).

[FN63]. See, e.g., Berring, supra note 5, at 33-34 (system of headnotes becomes strait-jacket for thought); Henige, supra note 20 (Library of Congress system "Euro-centric," replicates traditional thought, uses culturally insensitive language). For an overview of the problem of white, Western male bias in the Library of Congress subject headings and suggestions for reform, see Dwyer, supra note 9, at 3-8. Dwyer's subject, Sanford Berman, is one of the most outspoken critics of the Library of Congress subject heading policies. See S. BERMAN, supra note 9; see also Birdsall, supra note 62, at 75-77 (librarianship reflects liberal Western culture); Holley, supra note 19, at 30 (Library of Congress Subject Headings reflects American cultural biases); Kirtland \& Cochrane, supra note 20, at 87 (articles critical of sexism, prejudice intrinsic to Library of Congress Subject Headings).

For references to the insensitivity of the Library of Congress Subject Headings to ethnic groups, see, e.g,. COMMITTEE FOR THE DEVELOPMENT OF SUBJECT ACCESS TO CHICANO LITERATURE, supra note 9 (Chicano librarians' effort to improve access to Mexican American materials); Chabrán, supra note 9, at 384 (library language reflects government's "negative value judgments about ... Latino culture").

For the insensitivity of the Library of Congress Subject Headings to women, see, e.g., A WOMEN'S THESAURUS viii (M.E.S. Capek ed. 1988) (gender-neutral terms may reflect implicit male norms, and some traditional juxtapositions of subtopics, e.g., prostitution and lesbian issues, may condition user responses); R. DICKSTEIN, V. MILLS \& E. WAITE, supra note 9 (aid to locating materials of interest to women among gender-neutral subject headings).

For the insensitivity of Library of Congress Subject Headings to non-Western materials, see, e.g., CATALOGING AND CLASSIFICATION OF NON-WESTERN MATERIALS: CONCERNS, ISSUES, AND PRACTICES (M. Aman ed. 1980) (essays on African, Asian, Arabic, Slavic, and Hebraic cataloging); ZIAUDDIN SARDAR, ISLAM: OUTLINE OF A CLASSIFICATION SCHEME 16-17 (1979) (Library of Congress Subject Headings shows pro-Christian bias).

For an argument that the Library of Congress Subject Heading is unsuccessful in dealing with works written on more than one level, i.e., where "intellectual subjects" are distinct from "ostensible subjects," see Christopher Winters, Subject Access to Urban Studies Monographs, 5 CATALOGING \& CLASSIFICATION Q., no. 1, 1984, at 61, 77-80.

[FN64]. See Barkan, supra note 7, at 632 ("[L]egal resources can reinforce and reify dominant ideologies, can narrow perspectives, and can make contingent results seem inevitable....Key numbers, indexes, annotations, footnotes, and cross-references set the limits of inquiry."); Berring, supra note 5, at 36 ("The West system ... self-consciously attempted to maintain internal consistency and coherence in American law."); Dwyer, supra note 9 (indexers frequently leave out alternative, dissident, or maverick publications, citing space or economy grounds); Holley, supra note 19, at 29 ("subject cataloging ... has developed ... a self sustaining 
conservatism"); Mark Pendergrast, In Praise of Labeling; or, When Shalt Thou Break Commandments?, LIBR. J., June 1, 1988, at 83, 84 (indexing and cataloging essentially arbitrary, concealing political value judgments which favor or condemn particular works); Margaret F. Stieg \& Joan L. Atkinson, Librarianship Online: Old Problems, New Solutions, LIBR. J., Oct. 1, 1988, at 48, 51 (online database indexers frequently leave out alternative, nonconformist publications because selection and indexing are capricious and inconsistent).

[FN65]. See, e.g., DERRICK BELL, AND WE ARE NOT SAVED (1987); Kimberlé Williams Crenshaw, Race, Reform, and Retrenchment: Transformation and Legitimation in Antidiscrimination Law, 101 HARV. L. REV. 1331(1988); Richard Delgado, Derrick Bell and the Ideology of Racial Reform: Will We Ever Be Saved? (Book Review), 97 YALE L.J. 923 (1988); Alan David Freeman, Legitimizing Racial Discrimination Through Antidiscrimination Law: A Critical Review of Supreme Court Doctrine, 62 MINN. L. REV. 1049 (1978); Patricia J. Williams, Alchemical Notes: Reconstructing Ideals from Deconstructed Rights, 22 HARV. C.R.-C.L. L. REV. 401 (1987); Robert A. Williams, Jr., Taking Rights Aggressively: The Perils and Promise of Critical Legal Theory for Peoples of Color, 5 LAW \& INEQUALITY 103 (1987).

[FN66]. Richard Delgado, The Imperial Scholar: Reflections on a Review of Civil Rights Literature, 132 U. PA. L. REV. 561 (1984).

[FN67]. E.g., D. BELL, supra note 65, at 51-74; DERRICK A. BELL, JR., RACE, RACISM AND AMERICAN LAW 40-44 (1980).

[FN68]. D. BELL, supra note 67, at 40-44; Delgado, supra note 66; Charles R. Lawrence III, The Id, the Ego, and Equal Protection: Reckoning with Unconscious Racism, 39 STAN. L. REV. 317 (1987).

[FN69]. E.g., Delgado, supra note 65, at 930-32.

[FN70]. Id.; D. BELL, supra note 65, at 140-61; Freeman, supra note 65.

[FN71]. E.g., D. BELL, supra note 67, at 51-74; Delgado, supra note 66; Lawrence, supra note 68: see Mari J. Matsuda, Looking to the Bottom: Critical Legal Studies and Reparations, 22 HARV. C.R.-C.L. L. REV. 323 (1987).

[FN72]. Cf. Dwyer, supra note 9 (indexers often fail to appreciate and create categories for divergent, emerging perspectives); Stieg \& Atkinson, supra note 64 (same); Wise, supra note 8 (Critical Legal Studies research hindered by lack of subject headings and cross-references).

[FN73]. See, e.g., 27 INDEX TO LEGAL PERIODICALS 94 (1988); 6-7 NINTH DECENNIAL DIGEST, pt. 2 (1988) (civil rights).

[FN74]. See, e.g., 27 INDEX TO LEGAL PERIODICALS 170 (1988); 7-8 NINTH DECENNIAL DIGEST, pt. 2 (1988) (constitutional law).

[FN75]. See, e.g., 27 INDEX TO LEGAL PERIODICALS 166 (1988); 35 NINTH DECENNIAL DIGEST, pt. 2 (1988) (schools).

[FN76]. The three major indexes are devoid of these or similar headings and would be almost useless to a scholar researching these themes. However, a recent guide to computer searching, WILLIAM STATSKY, WEST'S LEGAL THESAURUS/DICTIONARY: A RESOURCE FOR THE WRITER AND THE COMPUTER RESEARCHER (1985), lists legitimation and hegemony, but not interestconvergence. Using these terms and their synonyms would enable the diligent researcher to find some critical law review articles from among the small number in computer databases. See Sunhee Juhon, CLS: A Pathfinder into the Gospel of Radical Reformation, 8 LEGAL REFERENCE SERVICES Q., nos. 3/4, 1988, at 107, 109 (Library of Congress lacks heading for critical legal 
studies); Laura Peritore, LEGALTRAC and WILSONDISC: A Comparison, 8 LEGAL REFERENCE SERVICES Q., nos. 3/4, 1988, at 233, 238 (only 19 articles assigned to heading "critical legal studies" in Index to Legal Periodicals; author lists many critical legal studies articles indexers missed); Wise, supra note 8 (critical legal studies material difficult to find in databases).

Readers may be interested to note, however, that the Library of Congress Subject Headings does contain a heading for "World War III." LIBRARY OF CONGRESS SUBJECT HEADINGS, supra note 11 , at 4121 .

[FN77]. Compare 26 INDEX TO LEGAL PERIODICALS xxxi (1987) (no entry for critical legal studies) with 27 INDEX TO LEGAL PERIODICALS xxxiv (1988) (entry for critical legal studies first appears).

[FN78]. See 31 NINTH DECENNIAL DIGEST, pt. 2 (1988) (municipal corporations).

[FN79]. See William Mischo, Library of Congress Subject Headings: A Review of the Problems, and Prospects for Improved Subject Access, 1 CATALOGING \& CLASSIFICATION Q., nos. 2/3, 1982, at 105, 108 (Library of Congress Subject Headings placed works on interracial marriage under "misćegenation'D').

[FN80]. 27 INDEX TO LEGAL PERIODICALS 491 (1988); 43 NINTH DECENNIAL DIGEST, pt. 2 (1988) (see, e.g., "Negroes" in descriptive word index for various topics with social subcategories).

[FN81]. Possible choices include Jurisprudence, Civil Rights, Legal Education, Legal Bibliography, and Law and Society.

[FN82]. E.g., 27 INDEX TO LEGAL PERIODICALS 170, 489, 540 (1988); 42 NINTH DECENNIAL DIGEST, pt. 2, at 492-93 (1988); 5 NINTH DECENNIAL DIGEST, pt. 1, at 9.10, 9.14 (1982); 9 CURRENT LAW INDEX, pt. A, at 243, 733 (1988).

[FN83]. See Kimberle Crenshaw, Demarginalizing the Intersection of Race and Sex: A Black Feminist Critique of Antidiscrimination Doctrine, Feminist Theory and Antiracist Politics, 1989 CHI. LEGAL F. 139, 141-52.

[FN84]. Id. at 139-43.

[FN85]. See generally id.

[FN86]. Their political weakness and Congress's lack of foresight obviously contributed as well. See note 90 infra (problem of spousal battery received little attention until coining of name led to creation of category).

[FN87]. See Berring, supra note 8, at 25-27 (computers help liberate us from time-worn categories of legal thought).

[FN88]. For a case dealing with concepts that are not referred to by name, see United States $\mathrm{V}$. Berrigan, 283 F.Supp. 336 (D.Md. 1968), aff'd sub nom., United States v. Moylan, F.2d 1002 (4th Cir. 1969) (Catholic priest convicted of dousing Selective Service files with blood in protest against Vietnam war, but the district court does not refer to civil disobedience by name). For articles dealing with concepts that are not referred to by name, see Berring, supra note 5, at 48 ("The fact is that law involves ideas, and ideas are not directly correlated with particular words."); Steven Alan Childress, The Hazards of Computer-Assisted Research to the Legal Profession, 55 OKLA. B.J. 1531, 1533 (1984) (computers' focus on words grounds searches in language, rather than content, of an opinion); John O. Cole, Thoughts from the Land of And, 39 MERCER L. REV. 907, 924-26 (1988); Dabney, supra note 33, at 19 (simple word-and- 
connector combinations that form basis of computer searches miss the more subtle meanings contained in word relationships).

Studies by the Norwegian Research Center for Computers and Law showed that $15 \%$ to $25 \%$ of failures to retrieve relevant documents were due to the fact that no single word or set of synonyms represented the idea sought by the researcher. Jon Bing, Performance of Legal Text Retrieval Systems: The Curse of Boole, 79 L. LIBR. J. 187, 193 (1987). For a discussion of articles and cases dealing with concepts that are referred to by name, but are not included in standard legal databases, see Wise, supra note 8 (early critical legal studies materials often absent from databases).

[FN89]. Professor J. Myron Jacobstein stumped demonstrators of the new LEXIS system at a 1975 convention with a challenge to find a certain case concerning a child. Jacobstein knew, but the demonstrators did not, that the judge had consistently called the child an "infant." Berring, supra note 5, at 38-39.

[FN90]. For example, one author notes:

[t]hat which goes unnamed may exert considerable influence over us, but because we have no words for it we cannot address it directly or deal with it. One example is battering. Only in the last couple of decades have we had a word for battering. It was going on long before then, but it did not functionally exist until it was given a common, agreed-upon name. Nobody talked about it. No one was called a batterer or a victim of battering. No statistics were gathered about it. No safe houses were set up to shelter its victims; no funding was set aside to study or treat it. Once it had a name, though, it became an acknowledged reality in our society. Individuals could say, "I've been battered," or "I've been a batterer." They could talk about their experience and thus validate it.

ANNE WILSON SCHAEF, WHEN SOCIETY BECOMES AN ADDICT 9 (1987). See also Berring, supra note 5 (higher order concepts reside not in words but in complex syntactical relationships among them); Bing, supra note 88 (same); Childress, supra note 88 (same); Cole, supra note 88 (same); Dabney, supra note 33 (computer searching puts search in hands of searcher unaided by skills trained indexer can provide (at 20); effectiveness drops as size of database increases (at 21-26); percentage of relevant documents found often lower than searcher believes (at 26-31)); Rita Reusch, The Search for Analogous Legal Authority: How to Find It When You Don't Know What You're Looking for?, 4 LEGAL REFERENCE SERVICES Q., no. 3, 1984, at 33; Wise, supra note 8.

[FN91]. Cf. Berring, supra note 5, at 39 (databases can only retrieve exact terms); Stieg \& Atkinson, supra note 64 , at $48,51,56$ (decisions to include or exclude material in databases often irrational).

[FN92]. Cf. Childress, supra note 88 (computer research can tempt searcher to sacrifice imagination, analogy, and policy for retrieval of strings of nondescript on-point cases); Reusch, supra note 90.

[FN93]. See Bing, supra note 88 ("output overload" a result of using Boolean logic to shape search commands); Lis Wiehl, Computers Assuming New Roles at Law Firms, N.Y. Times, Jan. 20, 1989, at 24, col. 2 (interview with Duncan Kennedy) (computer research will legitimize bias and oversimplification).

[FN94]. For discussions of the problem that imprecise, ambiguous and varying usage of language presents in full-text searching systems, see Berring, supra note 5, at 43-49; Dabney, supra note 33, at 7-20. See also David C. Blair \& M.E. Maron, An Evaluation of Retrieval Effectiveness for a Full-Text Document Retrieval System, 28 COMM. ACM 289 (March 1985) (publication of the Association for Computing Machinery) (inability of researchers to predict exact words and phrases resulted in system's retrieval of only $20 \%$ of relevant documents in 40,000 document files created for lawsuit). 
[FN95]. See Berring, supra note 5, at 60; Dabney, supra note 33, at 39; Studwell, supra note 19 , at 958 (keyword searching in computer-aided research no substitute for semantically effective subject heading system); cf. Scott F. Burson, Report from the Electronic Trenches: An update on Computer-Assisted Legal Research, 4 LEGAL REFERENCE SERVICES Q., no. 2, 1984, at 3, (criticizing indexing enhancements to computer-assisted legal research on two grounds: First, indexing becomes dated rapidly; and second, as in the precomputer days, enhancing would place too much reliance on a few vendors of legal research tools). WESTLAW has introduced indexing with its "Full-Text Plus," which condenses the key number system. See Dabney, supra note 33, at 31-34 for an explanation and criticism of Full-Text Plus.

[FN96]. See Holley \& Killheffer, supra note 20, at 126 ("[B]iased terms may have to remain as cross-references unless we are prepared to sacrifice access for patrons who are accustomed to using the biased alternative.").

[FN97]. Geneticist Richard Goldschmidt theorized that new types of organisms can arise suddenly as chance effects of major mutations, rather than gradually through the incremental changes posited by classical evolutionary theory. Goldschmidt called these new creatures "hopeful monsters," which may be an apt metaphor for the kind of thinker envisioned here. See STEPHEN JAY GOULD, THE PANDA'S THUMB 186-93 (1980) for a discussion of Goldschmidt. See also TRACY I. STORER \& ROBERT L. USINGER, GENERAL ZOOLOGY 199-200 (4th ed. 1965) (discussing "hybrid vigor"-the process by which a more vigorous, stronger offspring arises from the mating of individuals not closely related).

[FN98]. See Richard Delgado, Legal Storytelling for Oppositionists and Others: A Plea for Narrative, $87 \mathrm{MICH}$. L. REV. 2411 (1989) (on the role of peripheral groups in reforming law through telling of "counterstories").

[FN99]. See notes 65 \& 98 supra and accompanying texts.

[FN100]. E.g., The Legal System and Homosexuality-Approbation, Accommodation, or Reprobation?, 10 U. DAYTON L. REV. 445 (1985).

[FN101]. See D. BELL, supra note 65 (using narrative and parables to challenge racial myths); D. BELL, supra note 67; Derrick Bell, Brown v. Board of Education and the Interest-Convergence Dilemma, 93 HARV. L. REV. 518 (1980) (asserting that interests of blacks are accommodated only where they converge with interests of whites); Derrick Bell, The Supreme Court, 1984 Term-Foreword: The Civil Rights Chronicles, 99 HARV. L. REV. 4 (1985).

[FN102]. Richard K. Sherwin, A Matter of Voice and Plot: Belief and Suspicion in Storytelling, 87 MICH. L. REV. 543, 550-52 (1988) (noting necessity of balancing rhetoricians' search for belief and community with deconstructionists' suspicion).

[FN103]. See Sir Cyril Burt, Foreword to ARTHUR KOESTLER, THE ACT OF CREATION at 14-15 (1964).

[FN104]. W.E. BURGHARDT DUBOIS, THE SOULS OF BLACK FOLK 45 (1969).

[FN105]. See Delgado, supra note 98 (role of "outgroups" in telling "counterstories" and thus reforming law and legal culture); text accompanying notes 97-98 supra.

[FN106]. For example, current law practice has increased the pressure to generate billable hours and to specialize. Mega-firms are replacing smaller ones, and much of law practice is becoming routinized.

[FN107]. See notes 72-73 supra and accompanying text; notes 110-112 infra and accompanying text. 
[FN108]. Compare this approach with that suggested by Kennedy, supra note 7, at 210-11 (using Blackstone's famous work as template to lay out and analyze structure of traditional Western thought: "Blackstone serves both as a convenient starting point for the substantive history of American legal thought and as a relatively easy object for the method of discovering hidden political intentions beneath the surface of legal exposition"). See also William E. Benemann, American Graffiti, Library-Style, 18 AM. LIBR. 650 (1987) ("the lists provide a window on American society ... that may tell us more about ourselves than we could learn from 21 linear feet of statistical data"). Benemann further suggested studying the changes in index subject headings over time as a means of analyzing changes in our culture. See id. at 650 (comment on the Library of Congress Cataloging Service Bulletin's listings of "Subject Headings of Current Interest").

Another way to inspect the record, since the history of words reflects the history of ideas, is through historical lexicography-tracing words back to their earliest appearances in print and documenting changes in usage along the way. See Fred Shapiro, Legal Data Bases and Historical Lexicography, 3 LEGAL REFERENCE SERVICES Q., no. 4, 1983, at 85 (uses full-text retrieval systems to trace earliest use of terms like "executive privilege," "plea bargaining," and "reverse discrimination"); see also CURRENT INDEX TO LEGAL PERIODICALS, July 1988, at 1 (revised list of subject headings; 58 heads devoted to economic activity or legal procedure; 5 devoted to civil rights or rights of minority groups).

[FN109]. For a discussion highlighting the difficulty of discerning, apart from seeing the defects of, one's own conceptual system, see Delgado, supra note 65, at 928-47; Delgado, supra note 98.

[FN110]. Interview with Professor Trina Grillo, in San Francisco (Sept. 10, 1988).

[FN111]. Id.; cf. Carrie Menkel-Meadow, Portia in a Different Voice: Speculations on a Women's Lawyering Process, 1 BERKELEY WOMEN'S L.J. 39 (1985) (arguing that law is infused with patriarchal images, structures, and presuppositons); Diane Polan, Toward a Theory of Law \& Patriarchy, in THE POLITICS OF LAW: A PROGRESSIVE CRITIQUE, supra note 3, at 294, 299 (same); Nadine Taub \& Elizabeth M. Schneider, Perspectives on Women's Subordination and the Role of Law, in id. at 117 (same).

[FN112]. Cf. A WOMEN'S THESAURUS, supra note 63, at viii (indexing and classification systems lack vocabulary suited to retrieve many items of concern to feminists; these issues tend to be lumped together under "women" or other broad terms, e.g., lesbian issues categorized under sexuality, although many are nonsexual issues).

[FN113]. Most critics of legal research and indexing systems take this incrementalist view, urging, for example, that we work to make indexers any editors more sensitive to social change so that they more quickly incorporate it. See, e.g., Berman, supra note 19, at 80; Henige, supra note 20, at 13-16; Holley \& Killheffer, supra note 20, at 130-32; Kirtland \& Cochrane, supra note 20 , at 90 .

[FN114]. Most progressive librarians are quick to recognize and condemn active censorship. See Ron Seely, Censors Take More Liberty in Banning Books, Wis. St. J., Sept. 25, 1988, at 1, col. 1 (discussing campaign to remove controversial books). But the kind of unconscious selfcensorship we have been describing is much more difficult to detect and counter. The categories we use to screen and interpret reality seem natural and inevitable. We rarely question their adequacy or fairness. 
END OF DOCUMENT 